L. A. Rogers ${ }^{1}$ collected samples above and below a source of pollution on a stream. Above the pollution, the greater percentage of the organisms of the colon-aerogenes group were soil strains, while below the pollution, the greater percentage were fecal strains.

The variation in per cent of soil and fecal strains of organisms of the colon-aerogenes group from surface water supplies is shown graphically in the accompanying diagram.

TABLE IV-THE EFFECT OF DROUTH ON THE AVERAGE NUMBER OF ORGANISMS OF THE COLON-AEROGENES GROUP PER CC. IN SURFACE WATER ON THE AVERAGE NUMBER OF ORGANISMS GROWN ON AGAR AT $37^{\circ}$ IN

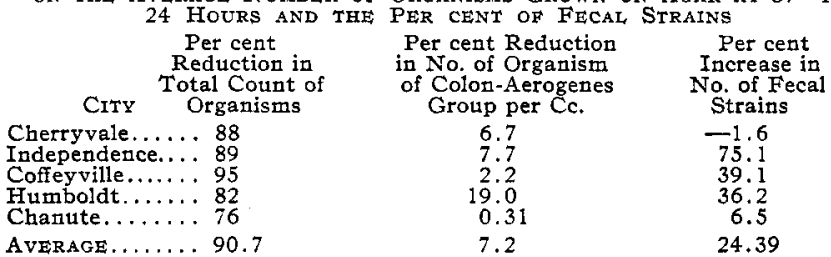

CONCLUSIONS

I-There seems to be no difference between soil and fecal strains of organisms of the colon-aerogenes group from surface water supplies in their resistance to treatment, nor is there a difference between cultures of the four principal groups of MacConkey, isolated from surface water supplies in their resistance to treatment.

2-There is a correlation between the increase in the fecal strains of organisms of the colon-aerogenes group during dry weather and the sanitary survey.

The writers wish to express their appreciation for the assistance and criticism of C. C. Young, Director of the Water and Sewage Laboratory, and C. A. Haskins, State Sanitary Engineer. The Kansas State Board of Health helped materially in the survey.

WATER AND SEWAGE Laboratory

State Board of Healte, Lawrence, Kansas

\section{THE EXAMINATION OF CANNED SALMON FOR BACTERIA AND TIN ${ }^{2}$}

By I. D. Bushneli and C. A. A. UtT

Received April 18, 1917

INTRODUCTION

Reports from the Division of Vital Statistics of the Kansas State Board of Health show a number of deaths in this state supposed to have been due to the eating of canned salmon. Data other than that are lacking. Mr. L. A. Congdon, Assistant Chief Food and Drug Inspector of the Kansas State Board of Health, suggested to us, through Dr. J. T. Willard, chief of the food laboratory of the Kansas State Agricultural College, the bacteriological examination of samples of canned salmon, with the view particularly of noting the presence of paratyphoid-like organisms. The state inspectors had sent in fifty-two samples of the various brands to the food laboratory for examination for tin. These were also used for bacteriological examination.

1 "The Viability of Different Types of the Colon-Group in Water," L. A. Rogers. J. of Bact. (Abstract), 1, 83.

2 Published by permission of W. M. Jardine, Dean of the Exp. Station, and J. T. Willard, Chief of the Food Laboratory, Kansas State Agricultural College, and S. J. Crumbine, Sec. Kansas State Board of Health.
The samples ranged from the most expensive to the cheapest grades on the market and included fortyfour different brands from twenty-six concerns.

The samples were obtained on the open market and we have no knowledge of the method of preparation.

All cans were in good condition and all held a vacuum, no swelled ends being found. All samples were offered for sale and were in a merchantable condition.

The fish was firm and of good flavor and odor in all cases. In some of the cheaper brands the meat was somewhat dry, light-colored and contained rather small amounts of oil, but these were not sold as a highgrade product.

The following commercial grades were examined:

$\begin{array}{ccccccc}\text { Grade: } & \text { Sockeye } & \text { Red Alaska } & \text { Chinook } & \text { Cohoe } & \text { Pink } & \text { Chum } \\ \text { Samples...... } & 8 & 24 & 2 & 2 & 10 & 6\end{array}$

\section{BACTERIOLOGICAL EXAMINATION}

The tops of the cans were carefully cleaned and covered with a 5 per cent solution of carbolic acid for about ro minutes. This was then poured off and denatured alcohol added for about 5 minutes. The excess of alcohol was removed and the remainder burned. The top was then thoroughly flamed with a Bunsen burner flame. The can was tilted several times, flamed again and opened with a previously boiled and flamed can opener, with as little agitation as possible. The floors, table top and hands of the operator were carefully washed with carbolic acid solution before the operation began.

Standard meat juice agar plates, dextrose fermentation tubes, bile lactose fermentation tubes, deep agar shakes, milk with and without calcium carbonate added, Endo agar plates and the condensation water on agar slants were inoculated. The material for these inoculations was taken from as near the bottom of the can as possible.

To the Petri dishes were added 2 cc., I cc. and 0 . I cc. of salmon liquor, about $0.5 \mathrm{cc}$. was added to the milk and fermentation tubes, a large loopful was added to the deep agar and to the condensation water of the agar slants. A part of the milk was heated to $85^{\circ} \mathrm{C}$. for ro minutes and cooled quickly in cold water. The agar shakes were also cooled quickly by plunging them into cold water as soon as inoculated. A large loopful of material was smeared upon a clean slide, fixed in absolute alcohol for I 5 minutes and stained in dilute methylene blue for $30 \mathrm{~min}$. All cultures were incubated at $37^{\circ} \mathrm{C}$. for 48 hours and careful examination made. They were placed at room temperature for 5 days and again examined.

As a check upon the methods, the increase in temperature of the contents of the can due to the flaming was noted but it was not infuenced. The media was checked against $B$. typhosus; $B$. enteritides; $B$. coli communis; $B$. paratyphosus, $A$ and $B ; B$. tetani; $B$. botulinus; $B$. anthracis symptomatici; and three cultures of $B$. Welchii, all of which grew readily.

As a check on the ability of organisms to grow in the salmon, thirteen samples taken at random were placed in test-tubes and inoculated with the first five 
organisms mentioned above. These were incubated at $37^{\circ} \mathrm{C}$. for $48 \mathrm{hrs}$. and examined microscopically for increase in number of organisms. In every case all grew very readily.

The results obtained from the bacteriological investigations were entirely negative. In a very few cases a mold developed on the plates and in one case a spore-forming organism developed. In no case did we find growth in fermentation tubes or deep agar or milk cultures. Stained slides were made from fermentation tubes in many cases, but no organisms were seen. No organisms were ever noted upon slides made directly from the cans.

About $50 \mathrm{~g}$. of this material from ro different brands were fed to white rats. They ate most of this in two days; after that they were kept for three weeks on ordinary feed, but failed to develop symptoms of any sort.

\section{EXAMINATION FOR TIN}

Twenty of the above samples were analyzed for their tin content. These included the best and cheapest brands on the market and were picked at random without any reference to their quality.

Tin determinations were made according to Journal of Official Association of Agricultural Chemists, Vol. II, No. 2, page 173 .

All tin determinations ran below $50 \mathrm{mg}$. per kilogram, showing they were well below the tolerance of $300 \mathrm{mg}$. per kilogram.

\section{CONCLUSIONS}

Canned salmon as found on the market in this state is sterile. It does not contain organisms of $B$. paratyphoid type, and does not contain aerobic or anaerobic spore formers. This is to be expected if the packers process their goods according to advertising material which they publish.

In one case they claim to heat the cans to $220^{\circ} \mathrm{F}$. for 50 mins., followed by a heating to $240^{\circ} \mathrm{F}$. for 60 mins. on a second day. This is necessary to protect the packers against loss of goods after it has been put on the market.

From the fact that this material will readily support the growth of pathogenic and other microörganisms, great care should be exercised in handling it after removal from the can.

Kansas State Agricultural College MaNhatTAN, KaNSAS

\section{THE INDUSTRIAL CHEMISTRY OF CHICLE AND CHEWING GUM ${ }^{1}$ \\ By Frederic DanNerTh}

The official estimate of chicle imported and converted in the United States in I9I 6 approximated $7,347,000$ $1 \mathrm{bs}$, equivalent to at least $30,000,000$ lbs. of chewing gum. An industry which has assumed these proportions may well be said to exert an influence on our national life. The retail selling price of the finished article is at the rate of $\$ \mathrm{I} .30$ per $1 \mathrm{~b}$., from which some idea of the financial strength of the industry may be obtained.

\footnotetext{
1 Presented at the 54th Meeting of the American Chemical Society, Kansas City, April 10 to $14,1917$.
}

In view of this it has become necessary to establish standard methods for the purchase of the Crude Block Chicle. As it arrives at the port of New York or New Orleans it contains a considerable amount of moisture-usually about 40 per cent. The factors which influence the purchaser may be summarized as follows:

(I) - The moisture the gum is estimated to contain.

(2)-The shrinkage when cleaned (dirt and bark).

(3)-The chewing quality of the clean purified chicle.

(4) - The color of the crude chicle.

\section{MOISTURE}

The amount of moisture contained in crude chicle was until very recently ascertained in the course of factory operations. For example, a roo-lb. lot was chopped up into $1 / 2$-in. crumbs and dried in a hot air chamber. The loss of weight was recorded as moisture. A somewhat better idea of the value of the chicle can be obtained by proximate analysis. Thus one sample of Yucatan chicle when examined in the laboratory showed:

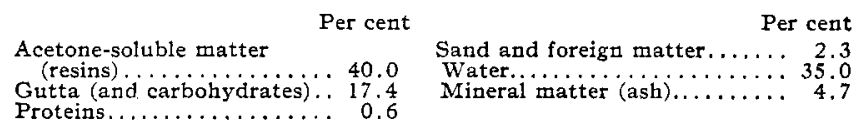

Obviously, if this chicle costs $\$ 0.55$ per $1 \mathrm{~b}$., crude, its value is $\$ 0.877$ per $1 \mathrm{~b}$. after drying and cleaning. In other words, Ioo lbs. of crude chicle in this case yielded $62.7 \mathrm{lbs}$. of dried and cleaned chicle.

SAMPLING-In sampling crude chicle after it has arrived at the factory a $\mathrm{I}-\mathrm{lb}$. sample is cut from a block. This is cut up into $1 / 2$-in. crumbs just as rapidly as possible. The crumbs are transferred to a "Lightning Jar" provided with a glass lid and rubber gasket. The jar should be not more than two-thirds full, leaving room for a thorough mixing by shaking the contents, and should be kept in a cool place to prevent caking. The large amount of moisture usually present in crude chicle makes it imperative to handle the sample rapidly. Wet chicle cannot be stored in sealed jars for more than one week as molds grow rapidly, especially if the jars are kept in the dark.

METHOD I-A weighed portion of crude chicle (about 5 g.) is dried in a well-ventilated air bath for 5 hrs. at a temperature not above $50^{\circ} \mathrm{C}$. As a container for the sample, a glass dish 2 or 3 in. in diameter with a ground glass lid is used. If the temperature in the oven rises, fusion will occur and evaporation of the water will be retarded. If the oven is poorly ventilated the drying will take longer. It is complete when two consecutive weighings vary not more than 0.5 per cent.

METHOD II-The moisture in crude chicle may be determined simultaneously with the determination of resins. Boiling acetone will remove resins and water from the sample by extraction. The extract in the flask is dried at $105^{\circ} \mathrm{C}$. and the residue in the thimble is dried in a similar manner. The sum of these weights subtracted from the weight of the 